\title{
Farklı Çinko Uygulamalarının Aspir Bitkisinin Verimi ve Çinko Alımı Üzerine Etkisi
}

\author{
Nurdilek GÜLMEZOĞLU* \\ Zehra AYTAC \\ Eskișehir Osmangazi Üniversitesi, Ziraat Fakültesi, Toprak Bilimi ve Bitki Besleme Bölümü, Eskișehir \\ Eskișehir Osmangazi Üniversitesi, Ziraat Fakültesi, Tarla Bitkileri Bölümü, Eskișehir
}

\begin{abstract}
*Sorumlu yazar e-posta (Corresponding author e-mail) : dgulmez@ogu.edu.tr
Geliș tarihi (Received) : 25.04.2016

Kabul tarihi (Accepted) : 07.09.2016
\end{abstract}

Öz

Bu araștırma, aspir bitkisine topraktan ve yapraktan uygulanan çinko (Zn) EDTA (Etilendiamintetraasetik asit) ve $\mathrm{Zn}$ sülfat $\left(\mathrm{ZnSO}_{4} \cdot 7 \mathrm{H}_{2} \mathrm{O}\right)$ kaynaklarının verim ve çinko içeriği üzerine etkilerini belirlemek amacıyla yürütülmüștür. Araștırmada çinko kaynakları kontrol, topraktan Zn-EDTA, yapraktan Zn-EDTA, toprak+yapraktan Zn-EDTA, topraktan $\mathrm{ZnSO}_{4}$, yapraktan $\mathrm{ZnSO}_{4}$, toprak+yapraktan $\mathrm{ZnSO}_{4}$ șeklinde uygulanmıștır. Çalıșmada materyal olarak Remzibey-05 çeșidi kullanıımıștır. Bitkide tabla sayısı ve tane verimi ile birlikte çiçeklenme ve hasat zamanında gövde+yapraklardaki ve tanedeki çinko konsantrasyonu ve içerikleri belirlenmiștir. Araștırma sonuçlarına göre, farklı çinko kaynakları ve uygulamaları tane verimini kontrole göre artırmıștır. Tane verimi, toprak+yapraktan Zn-EDTA uygulamasıyla, kontrole göre \% 21, toprak+yapraktan $\mathrm{ZnSO}_{4}$ uygulaması ile \% 16 oranında arttığı belirlenmiștir. Sonuç olarak, aspir bitkisine toprak+yapraktan Zn-EDTA uygulamasılyla en yüksek tane verimi ve tane çinko içeriği belirlenmiștir.

Anahtar Kelimeler: Carthamus tinctorius L., çinko içerik, çinko sülfat, çinko șelat

\section{The Influences of Various Zinc Applications on Seed Yield and Zinc Uptake of Safflower}

\begin{abstract}
This study was conducted to determine the effects of the zinc (Zn) EDTA (Ethylenediaminetetraacetic acid) and $\mathrm{Zn}$ sulphate $\left(\mathrm{ZnSO}_{4} .7 \mathrm{H}_{2} \mathrm{O}\right)$ sources on the yield and zinc content of seed at flowering and harvest stage of safflower. Zinc sources were applied in the forms of control, Zn-EDTA in soil, Zn-EDTA foliar spray, Zn-EDTA in soil + foliar spray, $\mathrm{ZnSO}_{4}$ in soil, $\mathrm{ZnSO}_{4}$ foliar spray and $\mathrm{ZnSO}_{4}$ in soil + foliar spray. The safflower cv. Remzibey-05 was used as material. The head number per plant, the seed yield and the zinc concentration and content of stem+leaf and seed at flowering and harvest stage were investigated. According to the results, different sources and applications of zinc increased seed yield when it compared with control. The application of Zn-EDTA in soil+foliar spray increased the seed yield $21 \%$ whereas $\mathrm{ZnSO}_{4}$ in soil + foliar spray increased seed yield $16 \%$ when it compared with the control. As a result, the highest seed yield and zinc content in seed of safflower were determined by the application of Zn-EDTA in soil+foliar spray.
\end{abstract}

Key Words: Carthamus tinctorius L., zinc content, zinc sulphate, zinc chelate 


\section{Giriș}

Bitkisel üretimde temel amaç birim alandan kaliteli ve yüksek verim almaktır. Verimi artırmak için de toprağın yapısı, verimlilik durumu ve özellikle de topraktaki besin elementlerinin bilinmesi gerekmektedir. Toprakta eksik olan elementlerin toprağa uygulanması ile verim ve kalite artıșı sağlanabilir. Bitkilerin verimi ve kalitesi üzerine önemli besin maddeleri olan makroelementlerin yanında son yıllarda mikro besin elementlerindeki eksikliklerin de önemli verim kayıplarına yol açtığını belirlenmiștir (MacNaeidhe ve Fleming, 1988; Erdem, 20111 . Mikro besin elementlerinden birisi olan çinko, bitki gelișimi için mutlak gerekli bir elementtir. Çinko, bitkide pek çok enzimde bulunmasının yanında, karbonhidrat, lipit, protein ve nükleik asit sentezlenmesinde ve parçalanmasında rol almaktadır (Cakmak 2000). Dünyada ve ülkemiz topraklarında çinko noksanlığı önemli bir problemdir. Türkiye toprakları çinkoyu, 10-300 ppm gibi yüksek düzeyde içermesine rağmen, toprakların \% 81,2 'lik bölümünde toprak pH'sının 7,0'nin üzerinde olması ve \% 57,6'sında kireç içeriğinin \% 5,0'in üzerinde olması çinko noksanlığının görülmesinin en büyük sebepleri arasındadır (Ülgen ve Yurtsever, 1984).

Yüksek $\mathrm{pH}$, kireç, $\mathrm{HCO}_{3}^{-}$, fosfor, bazı ağır metaller ve çok düșük organik madde içeriğine sahip problemli alanlara çinkonun nasıl uygulanacağı önemli bir sorundur. Alınabilir çinko kapsamları düșük olan topraklarda çinko gübrelemesinin verimi büyük ölçüde arttırdığı belirlenen pek çok sayıda araștırma bulunmaktadır (Brohi vd., 2000; Erdem, 2011 ). Bitkilere çinko uygulanması ile ilgili değișik uygulama yöntemleri mevcut olup, bunlar genellikle topraktan uygulama, yapraktan uygulama, tohuma bulaștırma, toprak+yapraktan uygulama șeklinde sıralanabilir. Bu uygulama șekillerinden bir ya da birkaçı ile çinko noksanlığı olan alanlarda verim ve kalitede önemli artıșlar sağlamaktadır (Yilmaz vd., 1997). Ancak insan ve hayvan beslenmesi için önem tașıyan tane çinkosunun artırıımasında çinko uygulama yöntemleri önemli farklılıklara yol açabilmektedir. Bu nedenle çinko noksanlığı olan alanlarda yapılacak olan yetiștiricilikte hem bitki gelișimi ve verimi hem de tane cinkosunun insan ve hayvan beslenmesi için önemli bir seviyede arttırılabilmesi bakımından farklı uygulama yöntemi ve/veya yöntem kombinasyonlarının etkisi her bitki tür ve çeșidi için ortaya konulması gerekmektedir.
Toprak koșullarına ve bitki özelliklerine göre uygun çinko formunun belirlenmesi de önemlidir. Çinko eksikliğinde inorganik tuz olan çinko sülfat $\left(\mathrm{ZnSO}_{4} \cdot 7 \mathrm{H}_{2} \mathrm{O}\right)$ genellikle çinko uygulamalarında kullanılan bir gübredir. Bir diğer çinko kaynağı ise çinko șelat (Zn-EDTA)'dır. Arpa ve buğdaya EDTA ve sülfat formunda çinko uygulanması ile ilgili yürütülen araștırmada, bitkilerin tane ve sap veriminin kontrole göre iki çinko formunda da arttığı, ancak Zn-EDTA formunun, diğer çinko kaynağından 1,4-1,7 oranında daha fazla artıș sağladığı belirlenmiștir (Brennan, 1991). Acre ve Unaran (1997), EDTA formunda toprağa uygulanan çinkonun, toprakta alınabilir haldeki süresinin iki günden az olduğunu ve bu nedenle bitkilerin gelișme dönemlerinde yeteri kadar çinko bulamadıklarını belirlemișlerdir. Bu durum șelat bileșiğindeki çinkonun, kalsiyum veya demir ile yer değiștirerek yarayıșsız forma geçmesine bağlı olarak açıklanmıștır (Mengel ve Kirkby, 1982). Aspir bitkisine de çinko uygulama yöntemleri, dozları ve zamanlarının verim ve kalite üzerine etkisini belirlemek amaçlı değișik çalıșmalar yürütülmüștür. Movahhedy-Dehnavy vd., (2009) üç aspir çeșidine, yapraktan $\mathrm{ZnSO}_{4}$ 'l rozet sonu ve çiçeklenme bașında uygulamıș ve çinko uygulamasının tohumdaki çinko ve tane protein içeriğini arttırdığını belirlemiștir. Bu çalıșmada, aspir bitkisine topraktan, yapraktan ve hem toprak hem de yapraktan farklı formdaki çinko $\left(\mathrm{ZnSO}_{4} .7 \mathrm{H}_{2} \mathrm{O}\right.$ ve $\mathrm{Zn}$-EDTA) uygulamalarının çiçeklenme ve hasat zamanında bitkinin tabla, tohum ve gövdesindeki çinko alımına, verim ve bazı verim öğelerine etkilerinin incelenmesi amaçlanmıștır.

\section{MATERYAL VE YÖNTEM}

Bu araștırma Eskișehir koșullarında 2010 yılında Eskișehir Osmangazi Üniversitesi Ziraat Fakültesi deneme tarlasında yürütülmüștür. Deneme alanı $39^{\circ} 45^{\prime} 55.38$ kuzey enlemleri ile 30033'02.27 doğu boylamları arasında yer almakta olup ilin denizden yüksekliği 789 m'dir.

Denemenin yürütüldüğü yıl, toplam yağıș miktarı $(418,1 \mathrm{~mm})$ uzun yıllar toplam yağıș miktarından $(331,6 \mathrm{~mm})$ yüksek, ancak vejetatif büyüme için önemli olan Nisan ve Mayıs aylarında elde edilen aylık yağıș miktarlarının uzun yıllar aynı aylara ait aylık yağıș miktarının altındadır. Deneme yılının ortalama sıcaklık değeri $\left(12,8^{\circ} \mathrm{C}\right)$, uzun yıllar sıcaklık ortalamasının $\left(10,6^{\circ} \mathrm{C}\right)$ üstünde, yıllık ortalama nem 
Çizelge 1 . Deneme toprağının bazı kimyasal ve fiziksel özellikleri

Table 1. Results of some physical and chemical analysis of soil

\begin{tabular}{|c|c|c|c|c|c|c|c|c|c|c|c|c|}
\hline \multirow[t]{2}{*}{$\mathrm{pH}$} & \multirow{2}{*}{$\begin{array}{c}\text { Toplam } \\
\text { Tuz } \\
(\%)\end{array}$} & \multirow{2}{*}{$\begin{array}{c}\text { Organik } \\
\text { madde } \\
(\%)\end{array}$} & \multirow{2}{*}{$\begin{array}{c}\mathrm{CaCO}_{3} \\
(\%)\end{array}$} & \multicolumn{3}{|c|}{ Tekstür (\%) } & \multicolumn{6}{|c|}{ Alınabilir (mg kg-1) } \\
\hline & & & & Kum & Silt & Kil & $P$ & K & $\mathrm{Zn}$ & $\mathrm{Fe}$ & $\mathrm{Mn}$ & $\mathrm{Cu}$ \\
\hline 7,72 & 0,18 & 1,9 & 10,5 & 44,7 & 17,1 & 38,2 & 6,46 & 636,45 & 0,30 & 1,94 & 9,02 & 1,47 \\
\hline
\end{tabular}

değeri $(\% 62,6)$ ise uzun yıllar ortalama nem değerine $(\% 63,8)$ benzer olarak belirlenmiștir.

Deneme alanının toprak özellikleri Çizelge 1'de verilmiștir. 0-30 cm derinliğinden alınan araștırma alanının toprak örneklerinde $\mathrm{pH}$ (toprak:su: 1:2.5) (Richards, 1954), toplam tuz (Richards, 1954), bünye (Bouyoucos, 1955), organik madde (Walkley ve Black, 1934), alınabilir fosfor (Olsen vd., 1954), potasyum (Caarson, 1980), demir, çinko, mangan, bakır (Lindsay ve Norvell, 1978) analizleri yapılımıștır. Araștırma alanının toprakları hafif alkalin, tuzsuz, tınlı, organik madde az, orta kireçli, alınabilir fosfor az, potasyum fazla, çinko az, demir az, mangan az ve bakırın yeterli seviyede olduğu belirlenmiștir (Lindsay ve Norvell, 1978; $\mathrm{FAO}, 1990)$.

Araștırma, Remzibey aspir çeșidi kullanılarak, tesadüf blokları deneme desenine göre, üç tekerrürlü olarak 29.03.2010 tarihinde dekara 4 kg tohum gelecek șekilde kurulmuștur. Ekim, $3 \mathrm{~m}$ uzunluğundaki parsellere, sıra arası $45 \mathrm{~cm}$ ve her parselde 6 sıra olacak șekilde yapılmıștır. Ekimle birlikte toprağa $8 \mathrm{~kg} \mathrm{P}_{2} \mathrm{O}_{5}$ da $^{-1}$ triple süperfosfat $(\%$ $\left.44 \mathrm{P}_{2} \mathrm{O}_{5}\right)$ ve $10 \mathrm{~kg}$ azot $\mathrm{da}^{-1}$ amonyum sülfat $(\%$ $20,5 \mathrm{~N}$ ) olarak uygulanmıștır.

Çinko uygulamalarl; kontrol (çinko uygulanmamıș), toprağa Zn-EDTA, yaprağa Zn-EDTA, toprak+yaprağa Zn-EDTA, toprağa $\mathrm{ZnSO}_{4}$, yaprağa $\mathrm{ZnSO}_{4}$, toprak+yaprağa $\mathrm{ZnSO}_{4}$ kombinasyonlarından olușturulmuștur. Topraktan çinko miktarları, dekara 2,5 $\mathrm{kg} \mathrm{ZnSO}_{4} .7 \mathrm{H}_{2} \mathrm{O}(\% 23$ $\mathrm{Zn}$ ) ve $\mathrm{Zn}$-EDTA (\% $15 \mathrm{Zn}$ ) gelecek șekilde ekimden önce bir kerede yüzeye sulandırılarak uygulanmıș ve sonra toprak karıștırılmıștır. Yapraktan çinko uygulaması, bir kez sapa kalkma döneminde (ekimden 80 gün sonra) \% 0,2 çinko ve bir kez de çiçeklenme döneminde (ekimden 95 gün sonra) \% 0,2 çinko olmak üzere iki kez sırt pülverizatörü ile her iki gübreden uygulanmıștır. Kontrol parsellerinde ise toprağa ve bitkiye herhangi bir çinko uygulaması yapılmamıștır. Bitkilerin hasadı Ağustos ayı sonunda yapiımıı̦tır.
Bitki örneklerinin çinko analizleri çiçeklenme sonunda ve hasatta olmak üzere her parselden tesadüfen seçilen 10 bitkide yapılmıștır. Kuru madde miktarının belirlenmesi için çiçeklenme döneminde bitkilerin tabla kısmı ayrı, gövde ve yapraklar beraber ve hasat zamanında bunlarla birlikte tohumlara da ayrılmıș bitki örnekleri, \% 0, l'lik HCl asit çözeltisinden geçirildikten sonra saf su ile yıkanarak $70^{\circ} \mathrm{C}^{\prime}$ de kurutulup, kuru ağırlıkları belirlenmiștir. Kurutulan bitkiler öğütüldükten sonra örneklerin çinko konsantrasyonunu belirlemek için $550^{\circ} \mathrm{C}^{\prime}$ de 8 saat kül fırınında yakılmıștır. Yakılan örnekler \% 3,3'lük $\mathrm{HCl}$ içinde çözündürülerek atomik absorbsiyon spektroskopi cihazında çinko konsantrasyonları $\left(\mathrm{mg} \mathrm{kg}^{-1}\right)$ belirlenmiștir. Bitki bașına çinkonun toplam miktarı (içerik) bir bitkinin yeșil aksamı ve tohumlarının kuru ağırlığıyla çinko konsantrasyonu $\left(\mathrm{mg} \mathrm{kg}^{-1}\right.$ ) çarpılarak (mg g bitki ${ }^{-1}$ ) hesaplanmıștır.

Hasat zamanında, parsellerdeki bitkilere ait olan tohumlar tartılarak parsel verimleri bulunmuș, sonra bu değerler dekara çevrilerek dekara tohum verimi hesaplanmıștır. Elde edilen verilerin MSTAT-C bilgisayar programı kullanılarak istatistiksel analizi yapılmıș, ortalamalar arasındaki farklar Duncan ile belirlenmiștir.

\section{BULGULAR VE TARTIȘMA}

Aspir bitkisine farkı içerikli çinko uygulamalarının çiçeklenme döneminde, gövde+yaprak kuru ağırlığında, hasat döneminde tek bitkiden elde edilen tohum veriminde önemli $(p<0,01)$ etkinin olduğu belirlenmiștir (Çizelge 2).

Aspirin çiçeklenme döneminde alınan bitki örneklerinde en yüksek toplam tabla kuru ağırlığı toprak+yaprak'tan Zn-EDTA uygulaması ve gövde+yaprak kuru ağırlığı ise topraktan $\mathrm{ZnSO}_{4}$ uygulamalarından elde edilmiștir. Hasat zamanı toplam tabla ağırlığını yapraktan Zn-EDTA, gövde+yaprak kuru ağırlığını topraktan $\mathrm{ZnSO}_{4}$ ve tek bitki tane ağırlığını toprak+yapraktan Zn-EDTA uygulamaları arttırmıștır. Kontrol bitkileri iki örnekleme döneminde de en düșük ağırlıklara sahip olmuștur. 
Çizelge 2. Aspir bitkisine uygulanan çinko formlarının çiçeklenme döneminde tek bitkide toplam tabla kuru ağırlığı ve gövde+yaprak kuru ağırlığı ile hasat döneminde tek bitkide toplam tabla kuru ağırlığı, gövde+yaprak kuru ağırlığı ve tane ağırlıklarına etkisi

Table 2. The effect of zinc forms on total dry weight of plant head per plant and total dry weight of stem+leaf per plant of safflower during flowering and harvest time and total seed weight per plant of safflower at harvest period.

\begin{tabular}{|c|c|c|c|c|c|}
\hline \multirow[b]{2}{*}{ Uygulamalar } & \multicolumn{2}{|c|}{ Ççceklenme } & \multicolumn{3}{|c|}{ Hasat } \\
\hline & $\begin{array}{c}\text { Toplam } \\
\text { Tabla } \\
\text { (g bitki }{ }^{-1} \text { ) }\end{array}$ & $\begin{array}{c}\text { Gövde+Yaprak } \\
\text { (g bitki }{ }^{-1} \text { ) }\end{array}$ & $\begin{array}{c}\text { Toplam } \\
\text { Tabla } \\
\text { (g bitki }{ }^{-1} \text { ) }\end{array}$ & $\begin{array}{c}\text { Gövde+Yaprak } \\
\text { (g bitki }{ }^{-1} \text { ) }\end{array}$ & $\begin{array}{c}\text { Tane } \\
\text { (g bitki }{ }^{-1} \text { ) }\end{array}$ \\
\hline Kontrol & 13,12 & $83,33 c$ & 13,98 & 115,32 & $31,39 d$ \\
\hline Zn-EDTA Topraktan & 14,02 & $110,93 b$ & 16,59 & 124,66 & $36,17 c$ \\
\hline Zn-EDTA Yapraktan & 14,26 & $122,27 a b$ & 19,04 & 133,52 & 43,30a \\
\hline Zn-EDTA Toprak+Yaprak & 15,58 & $113,67 b$ & 16,93 & 127,71 & $43,90 a$ \\
\hline $\mathrm{ZnSO}_{4}$ Topraktan & 13,92 & $127,63 a$ & 17,24 & 137,07 & $39,93 \mathrm{~b}$ \\
\hline $\mathrm{ZnSO}_{4}$ Yapraktan & 14,16 & $116,67 a b$ & 16,63 & 133,11 & 42,77ab \\
\hline $\mathrm{ZnSO}_{4}$ Toprak+Yaprak & 14,58 & $109,07 b$ & 15,96 & 129,71 & $41,70 a b$ \\
\hline F-test & ö.d. & $* *$ & ö.d. & ö.d. & $* *$ \\
\hline
\end{tabular}

ö.d.: önemli değil, **: $p<0,01$.

Aspir bitkilerinin tabla ve gövde+yaprak kuru ağırıkları çiçeklenme döneminde hasat zamanına göre daha düșük belirlenmiștir. Çinko uygulanmayan kontrol bitkilerine göre iki çinko formunun farklı uygulamaları aspir kuru ağırlığını artırdığı belirlenmiștir. Aspir bitkilerinin çiçeklenme döneminde en yüksek gövde+yaprak kuru ağırlığının topraktan uygulanan $\mathrm{ZnSO}_{4}$ gübresinden belirlenmesi vejetatif dönemde bitkilerin kökten $\mathrm{ZnSO}_{4}$ ile beslenmesinde katkısının yüksek olduğunu göstermektedir. Jan vd., (2016), çeltik bitkisinin vejetatif dönemde çinko sülfatın hızı yarayıșlı hale geçmesinden, olgunluğa doğru ise yavaș yarayıșlı hale geçen çinko șelattan daha iyi yararlanarak bitkilerin geliștiğini bildirmiștir. Bununla birlikte aspir bitkisinin kök yapısının kuvvetli olması (Bayramin, 2006) nedeniyle özellikle kurak bölgelerde topraktaki sudan ve besin elementlerinden de en iyi șekilde faydalanabilmektedir.

Hasat zamanı tek bitki tabla sayısı ve tane verimine ait veriler Çizelge 3'de gösterilmiștir. Tek bitki tabla sayısına cinko formları ve uygulama yöntemleri önemsiz, tane verimi üzerine ise önemli etkisinin $(p<0,01)$ olduğu belirlenmiștir. En yüksek tane verimi $\left(147,53 \mathrm{~kg} \mathrm{da}^{-1}\right)$ toprak+yapraktan ZnEDTA uygulamasından elde edilmiștir.

Toprak+yapraktan çinko uygulamalarından ZnEDTA uygulamasıyla kontrole göre \% 21 oranında tane veriminde artıș belirlenirken, $\mathrm{ZnSO}_{4}{ }^{\prime \prime \prime n}$ toprak+yapraktan uygulanması ile \% 16 artıș belirlenmiștir. Yapraktan çinko uygulamaları karșılaștıııldığında, $\mathrm{ZnSO}_{4} \%$ 18, Zn-EDTA \% 15 oranında tane verimini artırmıștır. Bazı araștırıcılar buğdaya yapraktan püskürtülerek uygulanan çinkonun tane veriminde önemli düzeyde artıșlar sağladığını belirtmiștir (Bayraklı vd., 1995; Kutman vd., 2010). MacNaeidhe ve Fleming (1988) arpada ve Brennan (1991) buğdayda yapraktan uygulanan çinko șelatın çinko sülfata göre tane verimini daha fazla artırdığını bildirmiștir. Modaihsh (1997) ise yapraktan uygulanan çinko sülfatın buğdayın tane verimini, Zn-EDTA'nın ise sap verimini artırdığını bildirmișlerdir. Topraktan çinko uygulanmasında tane verimini kontrole göre Zn-EDTA \% 12

Çizelge 3. Aspir bitkisine uygulanan çinko formlarının bitkide toplam tabla sayısı ve tane verimine etkisi

Table 3. The effect of zinc forms on total number of head per plant and seed yield of safflower

\begin{tabular}{lccc}
\hline Uygulamalar & $\begin{array}{c}\text { Bitkide Tabla Sayısı } \\
\text { (adet) }\end{array}$ & $\begin{array}{c}\text { Tane verimi } \\
\left(\mathrm{kg} \mathrm{da}^{-1}\right)\end{array}$ & $\begin{array}{c}\text { Kontrole göre verim artıș } \\
(\%)\end{array}$ \\
\hline Kontrol & 9,07 & $121,54 \mathrm{~d}$ & - \\
Zn-EDTA Topraktan & 10,67 & $136,12 \mathrm{bc}$ & 12 \\
Zn-EDTA Yapraktan & 11,53 & $139,54 \mathrm{abc}$ & 15 \\
Zn-EDTA Toprak+Yaprak & 11,47 & $147,53 \mathrm{a}$ & 21 \\
ZnSO $_{4}$ Topraktan & 10,00 & $133,13 \mathrm{c}$ & 10 \\
ZnSO $_{4}$ Yapraktan & 11,60 & $142,94 \mathrm{ab}$ & 18 \\
ZnSO $_{4}$ Toprak+Yaprak & 10,73 & $141,21 \mathrm{abc}$ & 16 \\
\hline F-test & o.d & $* *$ & \\
\hline
\end{tabular}

ö.d.: önemli değil, ${ }^{* *}: p<0,01$. 
artıırken, $\mathrm{ZnSO}_{4} \% 10$ artırmıștır. Taban vd., (1997), buğdayın tane verimini $\mathrm{Zn}$-EDTA'nın $\mathrm{ZnSO}_{4}{ }^{\prime}$ dan daha fazla arttırdığını bildirmiștir. Ancak su stresi koșullarında $\mathrm{ZnSO}_{4}$ formunun çinko șelat uygulamasına göre tohum verimini daha fazla artırdığını Lakzayi (2015) tarafından bildirilmiștir.

Aspir bitkisinin çiçeklenme ve hasat döneminde çinko konsantrasyonlarına ait ortalamalar ve uygulanan çinko formlarının etkileri Çizelge $4^{\prime}$ de verilmiștir. Hem çiçeklenme hem de hasat zamanında bitki örneklerinin çinko konsantrasyonları istatitistiksel olarak önemli $(p<0,01)$ bulunmustur. Çiçeklenme döneminde tablada çinko konsantrasyonu toprak+yapraktan Zn-EDTA uygulamasından, gövde+yaprakta ise yapraktan ZnEDTA uygulamasından en yüksek değerler elde edilmiștir.

Hasat zamanında tablada en yüksek çinko konsantrasyonu toprak+yapraktan Zn-EDTA uygulamasından, gövde+yaprak ve tohumda ise en yüksek çinko konsantrasyonu yapraktan Zn-EDTA uygulamasında belirlenmiștir. Bazı araștırııılar çeșitli bitkilere yapraktan çinko dozları uyguladıklarında, bitki aksamlarının çinko kapsamlarının artığını belirtmișlerdir (Taban ve Alpaslan, 1996; Haslett vd., 2001; Kutman vd., 2010). Bu araștırmada da yapraktan ya da toprak+yapraktan Zn-EDTA uygulamasının çiçeklenme ve hasatta aspir bitkisinin çinko konsantrasyonunu artırmıștır. Çinko sülfatın yapraktan uygulanmasında bitkinin çinko konsantrasyonu Zn-EDTA uygulaması kadar

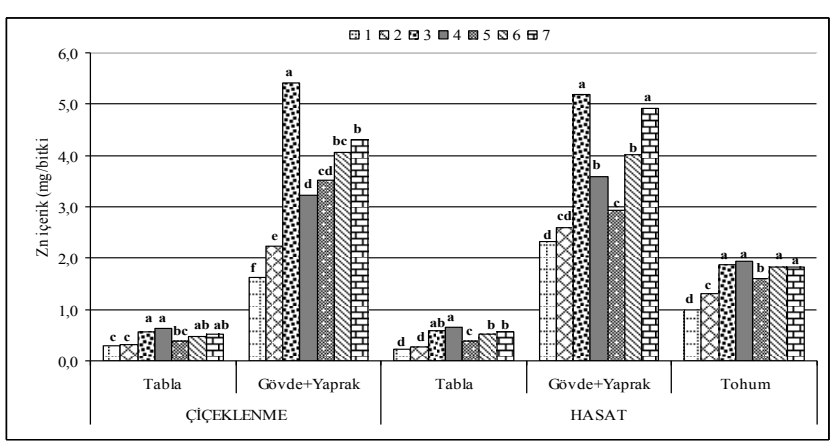

Șekil 1. Aspir bitkisine uygulanan çinko formlarının çiçeklenme ve hasat döneminde tabla, gövde+yaprak ve tane çinko içerikleri (mg g bitki ${ }^{-1}$ ) (1: kontrol 2: Zn-EDTA Topraktan, 3: Zn-EDTA Yapraktan, 4: Zn-EDTA Toprak+Yaprak, 5: $\mathbf{Z n S O}_{4}$ Topraktan, 6: $\mathrm{ZnSO}_{4}$ Yapraktan, 7: $\mathrm{ZnSO}_{4}$ Toprak+Yaprak)

Figure 1. The effect of zinc forms on zinc contents / $m g \mathrm{~g}$ plant') of head, stem+leaf and seed during flowering and harvest period 11: Control, 2: Zn-EDTA Soil, 3: Zn-EDTA Leaf, 4: Zn-EDTA Soil+ Leaf, 5: $\mathrm{ZnSO}_{4}$ Soil, 6: $\mathrm{ZnSO}_{4}$ Leaf, 7: $\mathrm{ZnSO}_{4}$ Soil+ Leaf) artırmamıș olması, aspir bitkisinin yapraktan șelat formunda çinko alımının daha kolay olabileceğini gösterebilir. Bu durum püskürtülen çinko sülfatın yaprakta deformasyon ya da yanmalara ve çinko konsantrasyonunun düșük belirlenmesine sebep olduğunu düșündürmektedir. Haslett vd., (2001), genelde bitkilere yapraktan uygulanan çinko formlarının alımında fazla farkın bulunmadığını bildirmiștir. Jan vd., (2016), çeltik bitkisinde çinko sülfatın yapraktan uygulanmasıyla, Zn-EDTA'dan daha fazla tane ve sap kısmında çinko konsantrasyonunu artırdığını, Zn-EDTA'nın ise topraktan uygulanmasıyla tane ve sap kısmında çinko konsantrasyonunu artırdığını belirtmiștir. Elde edilen bulgular, bu araștırmanın sonuçları ile benzerlik göstermektedir.

Farklı çinko formlarının çiçeklenme ve hasat döneminde, bitki aksamlarının çinko içeriklerine önemli etkisi $(p<0,01)$ belirlenmiștir (Șekil 1).

Çiçeklenme ve hasat dönemlerinde tablanın çinko alımı toprak+yapraktan Zn-EDTA uygulamasından, gövde+yaprağın çinko alımı ise yapraktan Zn-EDTA uygulanmasıyla en yüksek değer olarak tespit edilmiștir. Hasat döneminde tohumda en yüksek çinko alımı toprak+yapraktan Zn-EDTA uygulamasından elde edilmiștir. Ancak hem yapraktan $\mathrm{Zn}$-EDTA ve $\mathrm{ZnSO}_{4}$ hem de toprak+yapraktan $\mathrm{Zn}$-EDTA ve $\mathrm{ZnSO}_{4}$ uygulamaları, tohumun çinko alımları bakımından istatistiksel olarak aynı grupta yer almıș ve önemli bir fark belirlenmemiștir. Bu sonuç, Zn-EDTA ve $\mathrm{ZnSO}_{4}$ 'In yapraktan veya toprak+yapraktan uygulanması, tohum verimine ve çinko konsantrasyonuna etkisinin topraktan uygulanmasına göre daha yüksek olarak belirlenmesinden kaynaklanmaktadır (Çizelge 4).

Daha önce yapılan çalıșmalarda bitkilerin çinko alımına, çinkonun topraktan veya yapraktan uygulanmasının, bitki çeșidine ve yetiștirme șartlarına göre değiștiği saptanmıștır. Özellikle Haslett (2001) buğdaya yapraktan uygulanan çinko sülfatın etkin bir șekilde absorblanıp ve tașındığını belirtilirken, Goos vd., (2000) mısır bitkisine topraktan çinko șelat uygulamasının, bitkilerin çinko sülfattan daha fazla çinko içeriğine sahip olduğunu belirtmiștir. Ancak çinko șelatın zamanla alkalin toprakta azaldığını ve kalsiyum ile yer değiștirerek yarayıșsız hale geçtiği de bildirmiștir (Mengel ve Kirkby, 1982). 
Çizelge 4. Aspir bitkisine uygulanan çinko formlarının çiçeklenme ve hasat döneminde tabla, gövde+yaprak ve tanede çinko konsantrasyonları

Table 4. The effect of zinc forms on zinc concentrations of head, stem+leaf and seed during flowering and harvest period

\begin{tabular}{|c|c|c|c|c|c|}
\hline \multicolumn{6}{|c|}{ Zn konsantrasyonu (mg kg-1) } \\
\hline & & Çiçeklenme & & Hasat & \\
\hline Uygulamalar & Tabla & Gövde+Yaprak & Tabla & Gövde+Yaprak & Tohum \\
\hline Kontrol & $21,37 e$ & $19,55 \mathrm{e}$ & $15,7 d$ & $20,19 d$ & $31,39 d$ \\
\hline Zn-EDTA Topraktan & $21,90 \mathrm{e}$ & $19,74 \mathrm{e}$ & $16,7 d$ & $20,20 d$ & $36,17 c$ \\
\hline Zn-EDTA Yapraktan & $39,00 a$ & $45,90 a$ & $30,5 b$ & $38,80 a$ & 46,30a \\
\hline Zn-EDTA Toprak+Yaprak & $40,10 a$ & $29,35 d$ & $38,2 a$ & $28,15 c$ & $43,90 \mathrm{~b}$ \\
\hline $\mathrm{ZnSO}_{4} \mathrm{~T}$ & $27,85 d$ & $27,60 d$ & $23,3 c$ & $21,30 d$ & $39,93 \mathrm{bc}$ \\
\hline $\mathrm{ZnSO}_{4}$ Yapraktan & $31,40 c$ & $33,90 c$ & $30,9 b$ & $30,20 b$ & $42,77 b$ \\
\hline $\mathrm{ZnSO}_{4}$ Toprak+Yaprak & $36,50 \mathrm{~b}$ & $39,55 \mathrm{~b}$ & 35,1 a & $37,87 a$ & $43,70 \mathrm{~b}$ \\
\hline F-test & $* *$ & $* \star$ & $* *$ & $* \star$ & $* \star$ \\
\hline
\end{tabular}

$* *: p<0,01$

\section{SONUC̣LAR}

Araștırma sonuçlarına göre aspir bitkisinin tanesinde çinko içeriği yapraktan veya toprak+yapraktan uygulanan Zn-EDTA ile arttığı, tane verimini ise toprak+yapraktan Zn-EDTA uygulamasının arttırdığı tespit edilmiștir. Bu sonuç ile topraktan veya yapraktan uygulanan $\mathrm{ZnSO}_{4}$ gübresinin, $\mathrm{pH}$ ve kireç içeriği yüksek topraklarda, aspir tohumunun çinko birikimine ve tane verimine etkisinin, Zn-EDTA'dan daha az olduğu, özellikle toprak+yapraktan uygulanan Zn-EDTA'nın en etkin çinko uygulama yöntemi olduğu sonucuna varılmıștır.

\section{KAYNAKLAR}

Acre J P, Unaran D (1997). Üç değișik çinko gübresinin șeftali ağaçlarında rozetleșme önlenmesindeki etkinlikleri. 1. Ulusal Çinko Kongresi. s: 265-272. 12-16 Mayıs, Eskișehir.

Bayraklı F, Sade B, Gezgin S, Önder M, Topal A (1995). Çinko, fosfor ve azot uygulamasının Gerek 79 ekmeklik buğday çeșidinin (Triticum aestivum L.) tane verimi ve verim unsurları üzerine etkileri. Selçuk Üniversitesi Ziraat Fakültesi Dergisi, 6 (8): 116-130.

Bayramin S (2006). Aspir (Carthamus tinctorius L.) - Kolza (Brassica napus spp. oleifera L.) Tarımı ve Islahı. Tarla Bitkileri Merkez Araștırma Enstitüsü Dergisi, 15 (1-2): 74-85.

Bouyoucos G J (1955). A recalibration of the hydrometer method for making mechanical analysis of the soils, Agronomy Journal 4 (9): 434.

Brennan R F (1991). Effectiveness of zinc sulfate and zinc chelate as foliar sprays in alleviating zinc deficiency of wheat grown on zinc deficient soils in Western Australia. Australian Journal of Experimental Agriculture 31: 831-834.

Brohi A R, Karaata H, Özcan S, Demir M (2000). Topraktan ve yapraktan çinko uygulamasının ekmeklik buğday bitkisinin verim ve bazı besin maddesi alımına etkisi. Gaziosmanpașa Üniversitesi, Ziraat Fakülesi Dergisi, 17(1): 123-128.

Caarson P L (1980). Recommended potassium test. IN Recommended Chemical Soil Test Procedures for The North Central Region. Reu. Ed. North Central Regional Publication No.221. North Dakota Agric. Exp Stn. North Dakota State University Fargo. USA, pp. 20-21.
Cakmak I (2000). Role of zinc in protecting plant cells from reactive oxygen species. New Phytologist, 146: 185-205.

Erdem $H$ (2011). Silajlık mısır çeșitlerinin verim ve kalitesine çinko gübrelemesinin etkilerinin belirlenmesi.Gaziosmanpașa Üniversitesi, Ziraat Fakültesi Dergisi, 28(2): 199-206.

FAO (1990). Guidelines for soil profile description. 3rd edition (Revised), FAO, Rome.

Goos R J, Johnson B E, Thiollet M (2000). A comparison of the availability of three zinc sources to maize (Zea mays L.) under greenhouse conditions. Biology and fertility of soils, $31(3-4):$ 343-347.

Haslett B S, Reid R J, Rengel Z (2001). Zinc mobility in wheat: Uptake and distribution of zinc applied to leaves or roots. Annals of Botany, 87(3), 379-386.

Jan M, Anwar-ul-Haq M, Tanveer-ul-Haq, Ali A, Wariach E A (2016). Evaluation of Soil and Foliar Applied Zinc Sources on Rice (Oryza sativa L.) Genotypes in Saline Environments. International Journal of Agriculture and Biology. DOI: 10.17957/JJAB/15.0146, in press.

Kutman U B, Yildiz B, Ozturk L, Cakmak I (2010) Biofortification of durum wheat with zinc through soil and foliar applications of nitrogen. Cereal Chemistry 87: 1-9.

Lakzayi M (2015). Influence of foliar application on safflower yield. International Journal of Multidisciplinary Research and Development, 2 (12): 336-339.

Lindsay W L, Norvell W A (1978). Development of a DTPA soil test for zinc, iron, manganese, and copper. Soil Science Society of America Journal, 42(3): 42 1-428.

MacNaeidhe F S, Fleming G A (1988). A response in Spring cereals to foliar sprays of zinc in Ireland. Irish Journal of Agricultural Research, 27: 91-97.

Mengel K, Kirkby E A (1982). Principles of Plant Nutrition.International Potash Institute, Worblaufen -Bern, Switzerland, p. 1-665.

Modaihsh A S (1997). Foliar application of chelated and non-chelated metals for supplying micronutrients to wheat grown on calcareous soil. Experimental Agriculture 33: 237245. 
Movahhedy-Dehnavy M, Modarres-Sanavy S M A, Mokhtassi-Bidgoli A (2009). Foliar application of zinc and manganese improves seed yield and quality of safflower (Carthamus tinctorius L.) grown under water deficit stres. Industrial Crops and Products, 30: 82-92.

Olsen S R, Cole C V, Watanabe F S, Dean L A (1954). Estimation of available phosphorus in soils by extraction with sodium bicarbonate. United States Department of Agriculture Circular No: 939, Washington, D C, USA, p. 19.

Richards L A (1954). Diagnosis and Improvement of Saline and Alkali Soils. US Salinity Lab., (Ed.), United States Department of Agriculture Handbook, California, USA, 60:94.

Taban S, Alpaslan M (1996). Mısır Bitkisinin Çinko, Demir Bakır, Mangan ve Klorofil Kapsamı Üzerine Çinko Gübrelemesinin Etkisi. Pamukkale Üniversitesi Mühendislik Bilimleri Dergisi, 2(1): 69-73.

Taban S, Alpaslan M, Güneș A, Aktaș M, Erdal İ, Eyüpoğlu H, Baran İ (1997). Değișik șekillerde uygulanan çinkonun buğday bitkisinde verim ve çinkonun biyolojik yarayıșlılığı üzerine etkisi. 1. Ulusal Çinko Kongresi. s: 147-156. 12-16 Mayıs, Eskișehir

Ülgen N, Yurtsever N (1984). Türkiye gübre ve gübreleme rehberi. T.C Bașbakanlık Köy Hizmetleri Genel Müdürlüğü Toprak ve Gübre Araș. Enstitüsü Müdürlüğü Yayın No:209. Teknik Yayın No:66.

Walkley A, Black L A (1934). An examination of the Degtjareff method for determining soil organic matter and a proposed madification of the chramic acid titration method, Soil science, 37: 29-38.

Yilmaz A, Ekiz H, Torun B, Gultekin I, Karanlik S, Bagci S A, Cakmak I (1997). Effect of different zinc application methods on grain yield and zinc concentration in wheat cultivars grown on zinc-deficient calcareous soils. Journal of Plant Nutrition, 20: $461-471$. 